\title{
Aquatic macrophyte diversity of the Pantanal wetland and upper basin
}

\author{
Pott, VJ. ${ }^{\text {a* }}$ Pott, A. ${ }^{\mathrm{a}}$, Lima, LCP. ${ }^{\mathrm{b}}$, Moreira, SN. ${ }^{\mathrm{a}}$ and Oliveira, AKM. ${ }^{\mathrm{c}}$ \\ aPrograma de Pós-graduação em Biologia Vegetal, Departamento de Biologia, \\ Universidade Federal de Mato Grosso do Sul - UFMS, CP 549, CEP 79070-900, Campo Grande, MS, Brazil \\ bPrograma de Pós-graduação em Botânica, Universidade Estadual de Feira de Santana - UEFS, \\ Av. Transnordestina, s/n, CEP 44036-900, Feira de Santana, BA, Brazil \\ 'Programa de Pós-graduação em Meio Ambiente e Desenvolvimento Regional, Universidade Anhanguera - Uniderp, \\ Rua Alexandre Herculano, 1400, Jardim Veraneio, CEP 79037-280, Campo Grande, MS, Brazil \\ *e-mail: vali.pott@gmail.com \\ Received October 14, 2010 - Accepted December 13, 2010 - Distributed April 30, 2011
}

(With 1 figure)

\begin{abstract}
This is a short review of the state of the art concerning diversity of aquatic macrophytes and the main aquatic vegetation types in the Brazilian Pantanal wetland and upper watershed. There are $c a .280$ species of aquatic macrophytes on the Pantanal floodplain, with scarce endemism. On the upper watershed, Cerrado wetlands (veredas) and limestone springs have a distinct flora from the Pantanal, with twice the species richness. As a representative case of aquatic habitats influenced by river flood, some primary data are presented for the Pantanal Matogrossense National Park and associated Acurizal Preserve, analysing the floristic similarity among aquatic vegetation types. We comment on problems of conservation and observe that Panicum elephantipes Nees is one of the few natives to compete with the invasive Urochloa arrecta (Hack. ex T. Durand \& Schinz) Morrone \& Zuloaga.
\end{abstract}

Keywords: flora, aquatic plants, floodplain, savanna, vereda.

\section{Diversidade de macrófitas aquáticas do Pantanal e alta bacia}

\section{Resumo}

Esta é uma breve revisão sobre o estado do conhecimento sobre as macrófitas aquáticas e os principais tipos de vegetação do Pantanal brasileiro e da alta bacia. A flora da planície inundável é de aproximadamente 280 espécies, com escasso endemismo. Na alta bacia, as áreas úmidas do Cerrado (veredas) e nascentes em calcário têm flora distinta do Pantanal, com o dobro da riqueza de espécies. Como um caso representativo de ambientes aquáticos influenciados por inundação fluvial, são apresentados alguns dados primários do Parque Nacional do Pantanal mato-grossense e da Reserva Acurizal associada, analisando-se a similaridade florística entre tipos de vegetação aquática e comentandose os problemas de conservação na região, onde foi observado que a espécie Panicum elephantipes Nees é uma das poucas nativas que competem com a invasora Urochloa arrecta (Hack. ex T. Durand \& Schinz) Morrone \& Zuloaga.

Palavras-chave: flora, plantas aquáticas, campo úmido, savana, vereda.

\section{Introduction}

The first botanical reports on aquatic plants of the Pantanal come from European naturalists who crossed the region, as summarised by Sampaio (1916). Foremost among Brazilian botanists was the pioneering Hoehne (1923), who collected in the Pantanal, looking closely at aquatic plants, many of them mentioned in his book (Hoehne, 1948).

Then a gap occurred up until the last two decades, when local botanists started to give some information

on the regional flora (e.g. Pott and Pott, 1994, 1997). Various surveys on aquatic macrophytes of the sandy Pantanal, flooded by rain, have been previously reported (e.g., Pott et al., 1999). Some as yet unpublished data on the Pantanal Matogrossense National Park are presented, gathered by the authors and extracted from the Rapid Ecological Assessment-Botany report (Pott et al., 2001), as a representative case of aquatic vegetation influenced by river flood. 


\section{Results and Discussion}

\subsection{Flora}

Diversity of aquatic macrophytes in the Pantanal varies from the smallest (Wolffia brasiliensis Wedd.) to the largest hydrophyte, Victoria amazonica (Poepp.) Sowerby. There are at least 280 species of aquatic macrophytes in the Pantanal (Pott, 2008), most of them shown in the identification manual by Pott and Pott (2000), considering various degrees of dependence on water. The most numerous families are Poaceae (26), Cyperaceae (19), Fabaceae (15), Onagraceae (15) and Pontederiaceae (12), and the best represented genera are Ludwigia (15), Bacopa (12), Utricularia (11), Nymphaea (7), and Polygonum (7) (Pott and Pott, 2000; Pott, 2008).

Taxonomic work on aquatic plants in the Pantanal is as yet restricted to a few groups, such as Nymphaeaceae (Pott, 1998), Araceae-Lemnoideae (Pott and Cervi, 1999), Aeschynomene (Lima et al., 2006), and some genera have been reviewed on a Brazilian scale, such as Panicum (Guglieri and Longhi-Wagner, 2004). World-wide reviews such as Utricularia by Taylor (1989) are also very useful.

Research on macrophyte vegetation has been carried out mainly in floristics. It is often concentrated on a few spots, e.g., Pott et al. (1989, 1999) at Nhumirim ranch (Nhecolândia), Costa (2004) at Santa Emília ranch (Aquidauana), Nunes da Cunha et al. (2000) at Pirizal (Poconé) and other areas of Poconé (Prado et al., 1994; Schessl, 1999).

Cerrado wetlands (veredas) on the upper watershed and close by headwaters of the Paraná basin have a richer flora, with at least 574 species (Pott, 2008), twice the species richness found in the Pantanal. The flora of limestone springs on the Bodoquena upland is not very diverse but forms attractive underwater gardens (Pott, 1999).

Many aquatic plants which occur in the Pantanal are elements of wide distribution, in common with wetlands in other neotropical phytogeographic provinces, such as Amazonia and the Paraná basin. Veredas contain many additional Poaceae, Cyperaceae, Melastomataceae, etc., in common with other wet grasslands of South America.

There are floristic dissimilarities between the plain and the upper watershed (Pott, 2008), for example, in the crystalline streams of Bonito (Bodoquena range) grows Potamogeton illinoensis Morong (Pott, 1999), not yet found in the Pantanal, whereas the giant waterlily $V$. amazonica has exclusive occurrence in oxbow lakes of the lower floodplain (Pott, 2008). Also unique in Mato Grosso do Sul is the wetland sawgrass Cladium jamaicense Crantz (Pott, 2008), with Chara rusbyana M. Howe covering gaps, on organic soil upon sedimentary calcium carbonate. However, floristic similarity of the Pantanal with wet grasslands of the upper basin increases towards the Cerrado uplands, on the eastern sandy soil, with species in common such as Drosera sessilifolia A. St.-Hil., Echinodorus grandiflorus (Cham. \& Schltdl.) Micheli, Xanthosoma striatipes (Kunth \& Bouché) Mad., etc. Nevertheless, the grass-sedge community of Mauritia (M. flexuosa L. f.) palm wetlands in the headwaters and along cerrado streams of the upper basin is quite distinct from this palm formation on the plain (Pott, 2008), where it only occurs along a few rivers (Aquidauana and Taquari) (Silva et al., 2000) and is associated with species of seasonally flooded grassland or riparian scrub quite different from veredas.

Often there are large areas with assemblages dominated by a single macrophyte, such as species of Oryza and Polygonum, generally with strong vegetative propagation, or various communities may occur within a short distance. Some hydrophytes survive the dry season as dormant rhizomes, which is the case of Echinodorus spp., Eleocharis spp., Nymphaea spp., Sagittaria spp.. These are therefore among the first to reappear in the wet season, while others grow from seeds (Ludwigia spp.) and spores (Salvinia), and many use both vegetative and reproductive strategies. Year-round water level may vary up to $7 \mathrm{~m}$ in the river system, while fluctuation is much less in non-coalescent isolated ponds and most areas flooded only by rain. Flood cycles can be drawn from daily records taken by the Navy since 1900 at the hydrometric station at Ladário.

Some species are associated with lotic habitats, such as Ludwigia inclinata (L. f.) P.H. Raven, Nymphaea oxypetala Planch., but more often with lentic environments, while some occur in both, like Eichhornia azurea (Sw.) Kunth. Most sub-regions do not have lakes and ponds, and therefore have quite a monotonous landscape, compared to Nhecolândia, Rio Negro (part of Aquidauana) and Abobral, which present high diversity of habitats, such as brackish and fresh water ponds, seasonal streams, floodplain channels and ancient river beds ("corixos") and anabranches. Brackish ponds ("salinas") are poor in macrophyte species, where only Paspalum vaginatum $\mathrm{Sw}$. and charophytes occur. Along the Serra do Amolar there are large lakes (Vermelha, Uberaba, Mandioré, Gaíva, etc.), with aquatic vegetation restricted to shores and wind-sheltered inlets.

\subsubsection{Endemic and rare species}

The Pantanal is a Quaternary floodplain, geologically recent (Holocene), so very few endemic species occur, none of them aquatic. However, the endemic peanut Arachis vallsii Krapov. \& W.C. Greg. can be considered aquatic, as it grows in $40 \mathrm{~cm}$ flooded mud under Copernicia alba Morong, on the floodplain of Lake Baía Negra and in a few other clayey spots, where it flowers and sets fruit, with the advantage of its long hollow peg and stem, characteristic structures of aquatics. A few species are quite rare or show very restricted occurrence, such as Nymphaea belophylla Trickett, Eichhornia diversifolia (Vahl) Urb., Oryza grandiglumis (Döll) Prod., found near the Paraguay River in Cáceres, Discolobium psoraleaefolium Benth., collected only on the eastern part of the alluvial fan of the Taquari River. For instance, Eulophia alta (L.) Fawc. \& Rendl. has been found on an old floating island, Xanthosoma aristiguietae (Bunting) M. Madison, on the margins of the Miranda River to where rooting stems could have been carried in pre-Columbian times as a medicinal plant. 


\subsection{Life forms}

Aquatic macrophytes have been grouped according to their life form, into submerged, free floating, rooted floating, emergent and amphibious (Irgang et al., 1984), and epiphyte (Tur, 1972). Usually life form zoning occurs according to water depth: amphibians on the littoral, emergents on the shallow belts, and others in the deeper zones (Pott et al., 1989).

\subsection{Types of aquatic habitats and main vegetation types}

According to Silva et al. (2007), there is a total of $2,557 \mathrm{~km}^{2}$ of open water in the dry season of the Pantanal, considering only that with a vegetation-free surface. However, the flooded area varies from 7 to $70 \%$ of the Pantanal, so at high flood it may reach $110,000 \mathrm{~km}^{2}$, according to Hamilton et al. (1996), who used radar images, so also taking into account floating aquatics.

Floating mats ("camalote") and floating meadows ("baceiro", "batume") are both found in permanent water bodies such as ponds, lakes, canals, oxbows and rivers. The floating aquatic "batume" was defined by Da Silva (1984). Floating mats are attached banks of floating macrophytes, or they may not be anchored, so that they float downriver or may be driven by wind; the main species of these are the water hyacinths Eichhornia crassipes (Mart.) Solms and E. azurea (Sw.) Kunth, then both can be uprooted and become free-floating. On top of them and on free-floating aquatic plants (water lettuce, Pistia stratiotes L., water fern Salvinia auriculata Aubl.), Oxycaryum cubense (Poepp. \& Kunth) Palla starts to grow, with densely entangled long hollow roots and rhizomes, and gradually the floating mats become floating meadows, with denser vegetation, made up mainly of Eleocharis plicarhachis (Griseb.) Svenson, rooted on histosol, as long as the pond does not dry (Pivari et al., 2008). Histosol is a sort of organic soil made of decomposing plants (Neiff, 1978). As the floating meadow ages, the histosol thickens up to more than $1 \mathrm{~m}$, allowing humans to walk on it, as we have already done with a group of 10 people. This floating vegetation is most frequent in the Western zones, in the sub-regions of Abobral and Cáceres and along the Paraguay, Cuiabá, Negro, Miranda and Nabileque Rivers. The cover of bursedge, $O$. cubense, mats can be distinguished on Landsat and SPOT images (Abdon et al., 1998).

Swamps ("brejos") or permanently flooded or waterlogged areas are not as common as the rather misleading toponym Pantanal (= swampland) may suggest, and are confined to wetter places and those with fine sediments, near rivers, such as the Negro (sub-region Aquidauana), which overflows and disappears into a wide swamp, and parts of the sub-regions of Abobral, Paraguay and Poconé. Also, lately the increasingly flooded Taquari delta has become a swamp, due to silting of the river bed and consequent permanent overflow (Pott and Pott, 2005). It contains grasses and sedges, often with some becoming dominant such as giant sedge Cyperus giganteus Vahl ("pirizal"), Ipomoea carnea var. fistulosa (Mart. ex Choisy) D.F. Austin ("algodoal"), fireflag Thalia geniculata L. ("caetezal") and cat-tail Typha domingensis Pers. ("taboal"), growing in swampy areas or temporary ponds. Cat-tail tends to increase in disturbed flooded areas and artificial ponds (borrow pits and dredged water holes for cattle), while Rhynchospora trispicata (Nees) Steud. and Scleria variegata (Nees) Steud. are very frequently found.

\subsection{Annual cycle}

Aquatic plants respond well to the flood dynamics. Many shallowly flooded grasslands dry up and the seasonal aquatics disappear, among them even perennials, such as Pontederia parviflora Alexander and Sagittaria guayanensis Kunth, as do small annuals like Bacopa spp. and Echinodorus tenellus (Mart.) Buch. A difference is that in the Pantanal there is a stronger wet and dry cycle, whereas on the upper watershed the flood pulse is much lower, even where there is $50-100 \%$ more rainfall. Here soils remain waterlogged or with a high water table all year round, fed by ground water in the dry season, flowing over an impermeable layer of laterite, making the water ferruginous, or over basalt or sandstone. Plant distribution in cerrado wet grassland and vereda is related to groundwater level (Meirelles et al., 2002), yet in the Pantanal the water table may fall below $2 \mathrm{~m}$ in the dry season, hence above-ground water level in the wet is a more important factor. In parts of the Pantanal, these changes in the dry and aquatic phases are more pronounced, reflected in a high proportion of opportunistic therophytes (Schessl, 1999), on intermediate ground between floodless and deep flooded stretches. Vereda soils are more organic and peaty, acting like a water storing sponge. These soils are organosoils and gleysoils (Ramos et al., 2006). The soils in the Pantanal, even though hydromorphic too, vary from pure sand to heavy clay, but due to the very flat landscape, in the dry period the water table reaches the surface only in depressed parts, for example in ponds and water courses.

\subsection{Dynamics}

Aquatic vegetation in the Pantanal changes over time, starting with free-floating plants such as Salvinia spp., Pistia stratiotes, and Limnobium laevigatum (Humb. \& Bonpl. ex Willd.) Heine, which become colonised by the epiphyte Oxycaryum cubense (Pott and Pott, 2003) and later by Eleocharis plicarhachis (Pivari et al., 2008). In more permanent ponds and oxbow lakes, aquatic vegetation tends to advance to a later stage of floating meadow, building up a floating organic soil (histosol) (Neiff, 1978, 1982), which supports shrubs such as Ludwigia nervosa (Poir.) Hara and Rhynchanthera novemnervia DC. (Pivari et al., 2008) and even treelets, e.g. Cecropia pachystachya Trécul and Tabebuia insignis (Miq.) Sandw., until the pond eventually dries up and the floating meadow dies, and the process resumes in a new flood cycle (Pott and Pott, 2003). Nitrophilous terrestrial plants also appear, such as Erechtites hieracifolia (L.) Raf. ex DC., and the weedy tanner-grass Urochloa arrecta (Hack. ex T. Durand \& Schinz) Morrone $\&$ Zuloaga thrives on this organic substratum. Often the floating meadow is not attached, as an island, and moves 
around by wind, sometimes becoming stranded on the shore and decaying, recovering only if the water rises in time; it can be carried downstream and block a channel mouth or end up in the river, losing pieces due to collisions (banks, logs) or storms (1 m waves), and finally disintegrating.

\subsection{Indicator species}

In the Pantanal, dominance of free-floating plants (Pistia, Salvinia) indicates that the water body has dried off or the aquatic vegetation was removed by another disturbance. In the highlands, dense populations of Echinodorus macrophyllus (Kunth) Micheli, and Urospatha sagittifolia (Rudge) Schott indicate disturbed wetland, usually occurring near roads and on silted veredas (Pott and Pott, 2003), while Xanthosoma striatipes tends to increase under grazing. The submerged Ottelia brasiliensis Planch. increases in dammed streams.

\section{Pantanal Matogrossense National Park}

As a case study, some original data extracted from the unpublished report are presented about the National Park, gathered by the authors in the year 2001. So far, there is no published work on the aquatic vegetation of this Park and the adjacent Acurizal Preserve.

Seventeen sampling sites considered representative of the aquatic habitats (Table 1) were established, inspected by boat, or some on foot in the dry period, and plants were recorded at high and low waters. Plant specimens were collected, and are kept at the CGMS (UFMS) Herbarium. Plots were not measured and varied in area.

To obtain the floristic similarity among sampling sites of aquatic vegetation the Jaccard coefficient was used
(Figure 1); this is recommended for presence/absence data (Krebs, 1989). In addition, cluster analysis was performed using the Unweighed Pair Group Method with Arithmetic Mean (UPGMA) (Kent and Coker, 1992).

\subsection{Types of aquatic habitats}

The types of aquatic habitats and vegetation sampled were river, "corixo" (anabranch, oxbow), floating meadow, lake, pond, seasonal channel ("vazante"), backswamp and incoming stream.

The Alegre and Caracará Rivers are anabranches which run in a cutoff channel from the Cuiabá River to lake Baía dos Burros and other similar large open waters. The lakes show little aquatic vegetation cover, due to waves.

\subsection{Flora}

The floristic survey of various habitats at 17 sampling sites in the Park showed 135 species of aquatic macrophytes, nearly half the total number for the whole Pantanal. The most numerous families were Poaceae (15), Cyperaceae (10), Fabaceae (13), Onagraceae (9), Asteraceae (5), Convolvulaceae (5) and Euphorbiaceae (5), and the best represented genera were Ludwigia (13), Cyperus (10), Ipomoea (6), Panicum (6), Aeschynomene (5), Eleocharis (5), Utricularia (5) and Polygonum (5). These families and genera are typical of the Pantanal aquatic flora (Pott and Pott, 2000).

\subsection{Life forms}

The life forms are all present, albeit submerged, and some rooted floating plants are not common in the Park. It is surprising that not a single species of Nymphaea was detected, even though it is so easy to spot, and that seven

Table 1. Types of aquatic habitats and vegetation sampled in Pantanal Matogrossense National Park and Acurizal Preserve, Pantanal wetland, Brazil.

\begin{tabular}{lccc}
\hline \multicolumn{1}{c}{ Sites } & Abbreviation & Coordinates S, W & Habitat \\
\hline Acurizal Preserve & AP-1 & $17^{\circ} 48^{\prime} 31.3^{\prime \prime}$ and $57^{\circ} 34^{\prime} 34.8^{\prime \prime}$ & Seasonal stream \\
Acurizal Preserve & AP-2 & $17^{\circ} 48.47 .5^{\prime \prime}$ and $57^{\circ} 33^{\prime} 36.9^{\prime \prime}$ & Oxbow lake (shallow) \\
Baía Acurizal & BA-1 & $17^{\circ} 49^{\prime} 51.8^{\prime \prime}$ and $57^{\circ} 34^{\prime} 55.4^{\prime \prime}$ & Connected large oxbow \\
Baía Caracará & BC-1 & $17^{\circ} 51.32^{\prime \prime}$ and $57^{\circ} 26.86^{\prime \prime}$ & Delta lake \\
Baía Caracará & BC-2 & $17^{\circ} 51.71^{\prime \prime}$ and $57^{\circ} 26.23^{\prime \prime}$ & Delta lake \\
Baía dos Burros & BB-1 & $17^{\circ} 50^{\prime} 23.7^{\prime \prime}$ and $57^{\circ} 23^{\prime} 48.7^{\prime \prime}$ & Closed oxbow \\
Baía dos Burros & BB-2 & $17^{\circ} 49^{\prime} 19.6^{\prime \prime}$ and $57^{\circ} 22.57 .5^{\prime \prime}$ & Oxbow lake \\
Córrego Retiro & CR-1 & $17^{\circ} 50^{\prime} 29.8^{\prime \prime}$ and $57^{\circ} 33^{\prime} 35.4$ & Incoming stream \\
Córrego Zé Dias & CZ-1 & $17^{\circ} 52.06^{\prime \prime}$ and $57^{\circ} 30.09^{\prime \prime}$ & Bay of stream \\
River Cuiabá & RI-1 & $17^{\circ} 51^{\prime} 08.3^{\prime \prime}$ and $57^{\circ} 24^{\prime} 51.5^{\prime \prime}$ & Backswamp \\
Park houses & PH-1 & $17^{\circ} 50^{\prime} 45.4^{\prime \prime}$ and $57^{\circ} 24^{\prime} 12.3^{\prime \prime}$ & Pond \\
Park houses & PH-2 & $17^{\circ} 50^{\prime} 44.7^{\prime \prime}$ and $57^{\circ} 24^{\prime} 12.4^{\prime \prime}$ & Backswamp \\
River Alegre & AL-1 & $17^{\circ} 37^{\prime} 46^{\prime \prime}$ and $57^{\circ} 24^{\prime} 46^{\prime \prime}$ & Anabranch \\
River Araminho & AR-1 & $17^{\circ} 44.05^{\prime \prime}$ and $57^{\circ} 32.48^{\prime \prime}$ & Old river bed \\
River Araminho & AR-2 & $17^{\circ} 43.65^{\prime \prime}$ and $57^{\circ} 32.37^{\prime \prime}$ & Backswamp \\
River Caracará & RC-1 & $17^{\circ} 43.22^{\prime \prime}$ and $57^{\circ} 20.59^{\prime \prime}$ & Anabranch \\
River Caracará & RC-2 & $17^{\circ} 43.97^{\prime \prime}$ and $57^{\circ} 19.81^{\prime \prime}$ & Anabranch \\
\hline
\end{tabular}




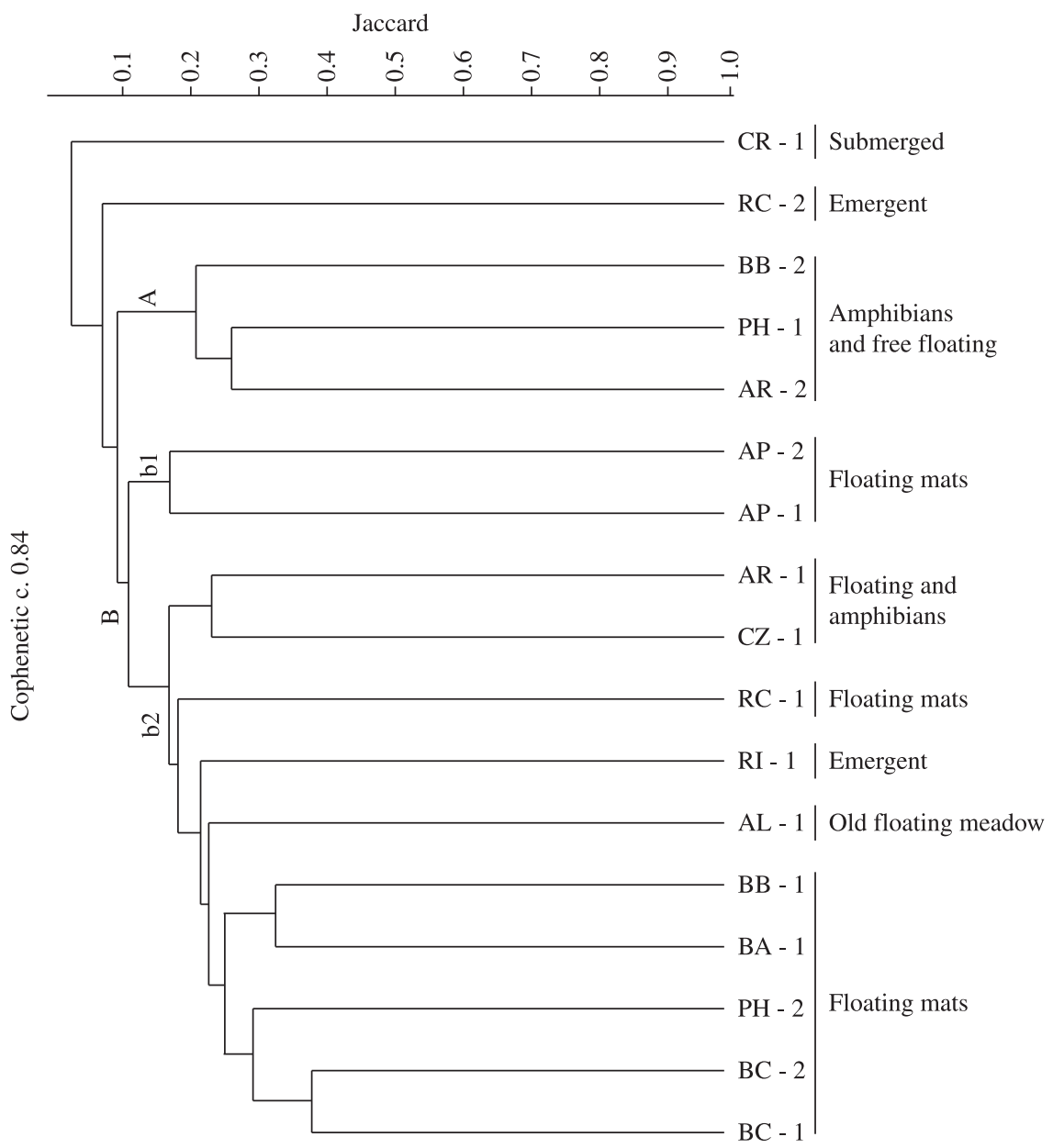

Figure 1. Dendrogram of floristic similarity among sampling sites of aquatic vegetation, grouped (separate vertical line on the right) according to their main habits, of Pantanal Matogrossense National Park and Acurizal Preserve, Pantanal wetland, Brazil. See Table 1 for names of sampling sites, coordinates and types of habitat.

species are found elsewhere in the Pantanal. Their absence is attributed to the low transparency of the water not allowing the young leaves to rise to the surface, although their relative Victoria succeeds in this. The turbid water would also explain the low number (five) of submerged species, four of them exclusive to the clear stream (CR-1) coming from the hill.

\subsection{Main aquatic communities}

Along rivers and streams there is a clear zoning of vegetation, seasonally dynamic: rooted floating mat (Eichhornia azurea, Paspalum repens Berg., Panicum elephantipes Nees) near the bank, then a sequence of emergent plants along the riverside, such as Panicum dichotomiflorum Michx. and Paspalum fasciculatum Willd. on the levee, oxbows and backswamps with free floating and emergent macrophytes, floating mats and floating meadows, and swamp of Aspilia latissima Malme. Thickets of this 1-2 m shrub, often mixed with Polygonum acuminatum Kunth, Ipomoea carnea Jacq. var. fistulosa (Mart. ex Choisy) D.A. Austin, and Cissus spinosa Cambess. are an intermediate stage between the aquatic vegetation and early successional phases of riparian forest, held back by flood and eventual wildfires. Well developed floating meadows occur on both sides of the anabranch Alegre River (AL-1), with treelets of Tabebuia insignis (Miq.) Sandw.), invaded by tanner-grass $U$. arrecta, while large emergent plants dominate in the anabranch Caracará River (RC-2) until further upstream becoming blocked by floating meadows. A typical oxbow lake (BB-1) is one connected to the Baía dos Burros lake, with free-floating plants and dead matter being colonised by the epiphytic Oxycaryum cubense plus dense mats of this sedge. Araminho River (AR) is an active old river bed, connected to the Paraguay River and anastomosed with its own oxbows.

\subsection{Species richness}

Species richness (Table 2) increases in wave-protected smaller water bodies and the older floating islands hold the highest number of species. On the floating meadow of the backswamp near the Park houses (PH-2) 45 species were found, nearly as many as on a floating meadow of 
Table 2. Species richness, exclusive and common species at sampling sites of aquatic vegetation of the Pantanal Matogrossense National Park and Acurizal Preserve, Pantanal wetland, Brazil (meaning of site names with coordinates is given in Table 1). Common: present in $\geq 7$ habitats.

\begin{tabular}{cccc}
\hline \multirow{2}{*}{ Sites } & \multirow{2}{*}{ Richness } & \multicolumn{2}{c}{ Species } \\
\cline { 3 - 4 } & & Exclusive & Common \\
\hline PH-2 & 45 & 10 & 14 \\
AL-1 & 42 & 0 & 12 \\
BC-2 & 40 & 1 & 15 \\
BC-1 & 34 & 9 & 7 \\
AR-2 & 34 & 4 & 11 \\
CZ-1 & 27 & 1 & 13 \\
BA-1 & 25 & 1 & 9 \\
RI-1 & 23 & 1 & 8 \\
AR-1 & 22 & 0 & 11 \\
BB-1 & 21 & 2 & 5 \\
PH-1 & 21 & 0 & 7 \\
RC-1 & 19 & 1 & 2 \\
C-2 & 13 & 0 & 5 \\
BB-2 & 13 & 2 & 5 \\
AP-1 & 12 & 1 & 5 \\
AP-2 & 11 & &
\end{tabular}

the anabranch Alegre River (AL-1) with 42, each with one third of the aquatic floristic richness. The lowest richness was found in two sites (AP-1 and 2) on floating mats of the Paraguay River, at Acurizal Preserve, with 12 and 11 species, respectively.

\subsection{Floristic similarity}

Floristic similarity among sampled sites is shown in Figure 1. Cophenetic correlation explains $84 \%$ of the data. Two groups are shown in the dendrogram, A and B, with low similarity (15\%). Group A joined sites AR-2, BB-2 and $\mathrm{PH}-1$, which are the Aspilia latissima backswamps, with $25 \%$ similarity for the first two and $30 \%$ for the third site. Two other sites stand out, CR-1 and RC-2, with low similarity, below $10 \%$; CR-1 is Córrego Retiro creek, with crystalline water from the hills, showing submerged species (Utricularia breviscapa Wright ex Griseb., U. hydrocarpa Vahl, and Egeria najas Planch.) and Ludwigia sedoides (Bonpl.) Hara, absent in the other sampled sites, whereas RC-2 is an extensive bank of large emergent plants (A. latissima, I. carnea, Polygonum spp.). Group B was divided in two subgroups, $b 1$ which linked AP- 1 and AP-2, with $18 \%$ similarity, and $b 2$ which joins sites AR-1, CZ-1, RC-1, RI-1, AL-1, BB-1, BA-1, PH-2, $\mathrm{BC}-2$, and BC-1, at different similarity levels (18 to $38 \%$ ). Groupings tend to show a sequence from floating mats (BB-1, BA-1, PH-2, BC-1 and 2) to inland sites farther from the Paraguay River. The floating meadows stayed apart due to the advanced succession stage of AL-1 compared to RC-2, though both are on anabranches.

\subsection{Frequency and cover}

Cover was visually estimated (in $1 \mathrm{~m}^{2}$ quadrats) for the main species per sampling site. The most frequent species and also showing the highest cover is Polygonum acuminatum, followed by Eichhornia crassipes with the second highest frequency, while E. azurea is the second in cover; the fourth in cover is Oxycaryum cubense (Table 3). So, only four species add to nearly half $(46.7 \%)$ of the overall cover of the sampled aquatic vegetation. Next in frequency are Vigna lasiocarpa, Hymenachne amplexicaulis, Mimosa pigra, Oxycaryum cubense, Aspilia latissima, Salvinia auriculata and Paspalum repens.

Even though Victoria amazonica is impressive in the landscape, it is not frequent in the study area and its population (Araminho River) was seen only during the flood period. This giant water-lily is very competitive and tends to dominate other plants, expanding its 1-2 m diameter leaves with their strong symmetric frame of ironwork-like nerves, until a single individual can cover up to $20 \mathrm{~m}^{2}$. Associated species such as E. azurea and Paspalum repens recolonise available space during the low water season.

Near the inselberg Morro do Caracará the large populations of native rice Oryza latifolia Desv. and O. glumaepatula Steud. represent important germplasm, so the Park has a role in in situ conservation. At low water, the flood-grown culms lie down, and are then often taken over by Hymenachne amplexicalis and Leersia hexandra, until their regrowth from nodes when the flood returns.

Lake Gaíva does not present macrophytes, only algae, indicated by the green colour of the water and the organic sediment, and by filaments on the shore.

\section{Use and Conservation}

Domestic animals, particularly horses, feed on aquatic plants, mainly grasses and sedges (Pott and Pott, 2004; Alho, 2008a,b). However, cows are usually removed from deep flooded areas or they spontaneously move to less flooded ground. Nevertheless, cattle remain year-round in rain-flooded zones, where they overgraze and trample waterlogged short soft grasslands around ponds and drainage lines. Buffaloes are known for damaging aquatic habitats. For instance, Pott et al. (1999) found 18 aquatic plant species in a pond with buffaloes, while 2 years after the removal of the animals the richness increased to 38 species. Fortunately buffalo are not liked by traditional ranchers, as they are difficult to manage and tend to become feral in this extensive type of husbandry, otherwise aquatic vegetation could be severely damaged, as has occurred in the Amapá wetlands in Amazonia. However, new owners have started to introduce buffalo again, as well as goats, both of which present a threat to the Pantanal.

Wildfire reaching dry beds is deleterious to hydrophytes with exposed buds, while it enhances seed germination of 
Table 3. Frequency and mean cover of the main aquatic macrophytes of Pantanal Matogrossense National Park and Acurizal Preserve, Pantanal wetland, Brazil.

\begin{tabular}{|c|c|c|}
\hline Species & Frequency $(\%)$ & Mean cover $(\%)$ \\
\hline Aspilia latissima Malme & 58.82 & 3.53 \\
\hline Urochloa arrecta (Hack. ex T. Durand \& Schinz) Morrone \& Zuloaga & 29.41 & 3.53 \\
\hline Cayaponia podantha Cogn. & 29.41 & 1.12 \\
\hline Discolobium pulchellum Benth. & 41.18 & 0.41 \\
\hline Echinochloa polystachya (Kunth) Hitchc. & 29.41 & 0.18 \\
\hline Eichhornia azurea (Sw.) Kunth & 58.82 & 11.24 \\
\hline Eichhornia crassipes (Mart.) Solms & 64.71 & 12.24 \\
\hline Eleocharis minima Kunth & 17.65 & 4.62 \\
\hline Hydrocotyle ranunculoides L.f. & 29.41 & - \\
\hline Hymenachne amplexicaulis (Rudge) Nees & 47.06 & 0.65 \\
\hline Ipomoea carnea $\mathrm{v}$. fistulosa (Mart. ex Choisy) Austin & 35.29 & 3.70 \\
\hline Leersia hexandra Sw. & 41.18 & 2.59 \\
\hline Lemna aequinoctialis Welw. & 29.41 & - \\
\hline Lippia alba (Mill.) N.E. Br. & 35.29 & 0.76 \\
\hline Ludwigia helminthorrhiza (Mart.) Hara & 41.18 & - \\
\hline Ludwigia leptocarpa (Nutt.) Hara & 29.41 & 1.12 \\
\hline Ludwigia nervosa (Poir.) Hara & 35.29 & - \\
\hline Melochia arenosa Benth. & 41.18 & 2.47 \\
\hline Mimosa pigra $\mathrm{L}$. & 47.06 & 1.24 \\
\hline Oxycaryum cubense (Poepp.\& Kunth)Lye & 47.06 & 9.06 \\
\hline Panicum elephantipes Nees & 41.18 & 2.24 \\
\hline Paspalum repens Berg. & 47.06 & 3.59 \\
\hline Pfaffia glomerata (Spreng.) Pedersen & 29.41 & 0.41 \\
\hline Pistia stratiotes $\mathrm{L}$. & 29.41 & - \\
\hline Polygonum acuminatum Kunth & 76.47 & 14.18 \\
\hline Polygonum ferrugineum Wedd. & 35.29 & 3.88 \\
\hline Pontederia parviflora Alex. & 41.18 & - \\
\hline Rhabdadenia madida Miers & 35.29 & 0.24 \\
\hline Salvinia auriculata Aubl. & 47.06 & 1.94 \\
\hline Vigna lasiocarpa (Benth.) Verdc. & 58.82 & - \\
\hline
\end{tabular}

weedy Mimosa spp. and Sesbania virgata (Cav.) Pers., shrubs which tolerate flooding and compete with other aquatic plants (Pott and Pott, 2003). Yet rhizomatous macrophytes such as Canna glauca L., Cyperus giganteus Vahl, Eleocharis spp., Thalia geniculata and Typha domingensis can survive and tend to become dominant (op. cit.).

Few exotic aquatic plants have invaded the Pantanal. One is Sphenoclea zeylanica Gaertn. (Sphenocleaceae, formely Campanulaceae), but it is restricted to the Paraguay River floodplain (Pott and Pott, 2000), even in undisturbed sites such as the National Park. Two introduced grasses have become weeds, torpedo-grass Panicum repens L. is spreading in sandy areas and tanner-grass Urochloa arrecta on clay (Pott and Pott, 2003). The latter is a real threat to aquatic vegetation diversity, propagated by seed, stolon, rhizome, or any fragment, carried by flood flow, taking over other aquatic plants, as is already happening in the Pantanal National Park, where we observed that the vigorous stoloniferous Panicum elephantipes is one of the only native grasses to match the competition.

Acknowledgements - To CNPq for the present research grant PQ2 to A. Pott and scholarship to LCP. Lima; to CAPES for the scholarship to S.N. Moreira; to Prof. Dr. Geraldo A. Damasceno-Junior (UFMS) for statistical support; to José Augusto Ferraz de Lima (director of Pantanal Matogrossense National Park), Gislaine e Adalberto Eberhardt (Ecotrópica and Acurizal Preserve) and The Nature Conservancy for logistic support; and to Dr. J.A. Ratter for critical review.

\section{References}

ABDON, MM., POTT, VJ. and SILVA, JSV., 1998. Avaliação da cobertura por plantas aquáticas em lagoas da sub-região da Nhecolândia no Pantanal por meio de dados Landsat e SPOT. Pesquisa Agropecuária Brasileira, vol. 33, no. especial, p. 1675-1681. 
ALHO, CJR., 2008a. The value of biodiversity. Brazilian Journal of Biology, vol. 68, no. 4, p. 1115-1118.

-, 2008b. Biodiversity of the Pantanal: response to seasonal flooding regime and to environmental degradation. Brazilian Journal of Biology, vol. 68, no. 4, p. 957-966.

COSTA, LC. 2004. Florística de macrófitas aquáticas em duas lagoas e três vazantes do IPPAN na Fazenda Santa Emília, planície de inundação do Rio Negro, Pantanal, Mato Grosso do Sul. Campo Grande: Universidade para o Desenvolvimento do Estado e da região do Pantanal. Monografia de graduação do curso de ciências biológicas.

DA SILVA, CJ., 1984. Nota prévia sobre o significado biológico dos termos usados no Pantanal Mato-grossense, "batume" e "diquada". Revista Universidade Federal de Mato Grosso, vol. 4, p. 30-36.

GUGLIERI, A. and LONGHI-WAGNER, HM., 2004. Panicum (Gramineae - Paniceae) Flora Ilustrada do Rio Grande do Sul, 26. Boletim do Instituto de Biociências UFRGS, vol. 59, p. 1-163.

HAMILTON, SK., ZIPPEL, SJ. and MELAK, JM., 1996. Inundation patterns in the Pantanal wetland of South America determined from passive microwave remote sensing. Archives of Hydrobiology, vol. 37, no. 1, p. 1-23.

HOEHNE, FC., 1923. Phytophysionomia do Estado de Matto Grosso e ligeiras notas a respeito da composição e distribuição da sua flora. São Paulo: Cia. Melhoramentos. $94 \mathrm{p}$

-, 1948. Plantas aquáticas. São Paulo: Secretaria da Agricultura. $168 \mathrm{p}$.

IRGANG, BE., PEDRALLI, G. and WAECHTER, JI., 1984. Macrófitos aquáticos da Estação Ecológica do Taim, Rio Grande do Sul, Brasil. Roessléria, vol. 6, p. 395-404.

KENT, M. and COKER, P., 1992. Vegetation description and analysis: a practical approach. London: Belhaven Press.

KREBS, JC., 1989. Ecological methodology. New York: Harper Collins Publ. 654 p.

LIMA, LCP., POTT, VJ. and SARTORI, ALB., 2006. Aeschynomene L. (Leguminosae, Papilionoideae, Aeschynomeneae) no Estado de Mato Grosso do Sul, Brasil. Hoehnea, vol. 33, no. 4, p. 419-453.

MEIRELLES, ML., OLIVEIRA, RC., SANTOS, AR. and CORREIA, JR., 2002. Espécies do estrato herbáceo e profundidade do lençol freático em áreas úmidas do Cerrado. Planaltina: Embrapa Cerrados. 19 p. Boletim de Pesquisa e Desenvolvimento, Embrapa Cerrados, no. 25.

NEIFF, JJ., 1978. Fluctuaciones de la vegetacion acuatica en ambientes en el valle de inundacion del Parana médio. Physics Sección B, vol. 38, no. 95, p. 41-53.

-, 1982. Esquema sucesional de la vegetacion en islas flotantes del Chaco argentino. Boletin de la Sociedad Argentina de Botánica, vol. 24 , no. $1-4$, p. $325-341$.

NUNES DA CUNHA, C., VILHALVA, DAA. and FERREIRA, H., 2000. Espécies de campo inundável e de brejo, Fazenda Retiro Novo, Pantanal de Poconé, MT (lista preliminar). In Anais do III Simpósio sobre Recursos Naturais e Sócio-Econômicos do Pantanal - Os desafios do novo Milênio. Corumbá: Embrapa Pantanal. p. 1-14.

PIVARI, MOD., POTT, VJ. and POTT, A., 2008. Macrófitas aquáticas de ilhas flutuantes (baceiros) nas sub-regiões do Abobral e Miranda, Pantanal, MS, Brasil. Acta Botanica Brasilica, vol. 22 , no. 2 , p. $563-571$.
POTT, A. and POTT, VJ., 1994. Plantas do Pantanal. Brasília: Embrapa. 320 p.

-, 2004. Features and conservation of the Brazilian Pantanal. Wetlands Ecology and Management, vol. 12, no. 6, p. 547-552.

-, 2005. Alterações florísticas na Planície do Baixo Taquari. In GALDINO, S., VIEIRA, LM. and PELLEGRIN, LA., Ed. Impactos ambientais e socio-econômicos na Bacia do Rio Taquari, Pantanal. Corumbá: Embrapa Pantanal. p. 261-293.

POTT, A., CUNHA, CN., POTT, VJ., SILVEIRA, EA. and SARTORI, ALB., 2001. Relatório Final. Avaliação ecológica rápida: Componente botânica - Parque Nacional do Pantanal Matogrossense e entorno. In Plano de Manejo do Parque Nacional do Pantanal Matogrossense. Ministério do Meio Ambiente. Anexo 4.

POTT, VJ. and CERVI, AC., 1999. A família Lemnaceae Gray no Pantanal (Mato Grosso e Mato Grosso do Sul). Revista Brasileira de Botânica, v. 22, no. 2, p. 153-174.

POTT, VJ. and POTT, A., 1997. Checklist das macrófitas aquáticas do Pantanal, Brasil. Acta Botanica Brasilica, vol. 11, no. 2 , p. 215-227.

-, 2000. Plantas Aquáticas do Pantanal. Brasília: Embrapa. 404 p.

-, 2003. Dinâmica da vegetação aquática do Pantanal. In THOMAZ, SM. and BINI, LM. Ecologia e manejo de macrófitas aquáticas. Maringá: Editora da Universidade Estadual de Maringá. p. 145-162.

POTT, VJ., 1998. A família Nymphaeaceae no Pantanal. Acta Botanica Brasilica, vol. 12, no. 2, p. 183-194.

-, 1999. Riqueza verde em meio azul. In SCREMIN-DIAS, E. Nos jardins submersos da Bodoquena: guia para identificação das plantas aquáticas de Bonito e região. Campo Grande: UFMS. p. 59-93.

-, 2008. Plantas de ambientes aquáticos e úmidos do Centro-Oeste brasileiro. In Anais do 59o Congresso Nacional de Botânica. Natal: Sociedade Brasileira de Botânica. p. 441-442.

POTT, VJ., BUENO, NC., PEREIRA, RAC., SALIS, SM. and VIEIRA, NL., 1989. Distribuição de macrófitas aquáticas numa lagoa na Fazenda Nhumirim, Nhecolândia, Pantanal, MS. Acta Botanica Brasilica, vol. 3, no. 2, p. 153-168.

POTT, VJ., CERVI, AC., BUENO, NC. and POTT, A., 1999. Dinâmica da vegetação aquática de uma lagoa permanente da Fazenda Nhumirim, Pantanal da Nhecolândia, MS. In Anais do II Simpósio sobre Recursos Naturais e Sócio-Econômicos do Pantanal, Manejo e Conservação, 1996. Corumbá: Embrapa Pantanal. p. 227-235.

PRADO, AL., HECKMAN, CW. and MARTINS, FR., 1994. The seasonal succession of biotic communities in wetlands of the tropical wet-and-dry climatic zone: II. The aquatic macrophyte vegetation in the Pantanal of Mato Grosso, Brazil. Internationale Revue der gesamten Hydrobiologie und Hydrographie, vol. 79, no. 4 , p. 569-589.

RAMOS, MVV., CURI, N., MOTTA, PEF., VITORINO, ACT., FERREIRA, MM. and SILVA, MLN., 2006. Veredas do triângulo Mineiro: solos, água e uso. Ciência Agrotécnica, vol. 30, no. 2, p. $283-293$

SAMPAIO, AJ., 1916. A flora de Matto Grosso: memória em homenagem aos trabalhos da Comissão Rondon. Archivos do Museu Nacional, vol. 19, p. 1-125.

SCHESSL, M., 1999. Floristic composition and structure of floodplain vegetation in the Northern Pantanal of Mato Grosso, Brazil. Phyton, vol. 39, no. 2, p. 303-336. 
SILVA, JSV., ABDON, MM. and POTT, A., 2007. Cobertura vegetal do bioma Pantanal em 2002. In Anais do XXIII Congresso Brasileiro de Cartografia. Rio de Janeiro: Sociedade Brasileira de Cartografia. p. 1030 -1038.

SILVA, MP., MAURO, RA, MOURÃO, GM. and COUTINHO, M., 2000. Distribuição de classes de vegetação do Pantanal através de levantamento aéreo. Revista Brasileira de Botânica, vol. 32, no. 2, p. 143-152.

TAYLOR, PG., 1989. The genus Utricularia: a taxonomic monograph. Kew: HMSO. 724 p. Royal Botanic Gardens. Kew Bulletin Additional Series, 14.

TUR, NM., 1972. Um caso de epifitismo acuático. Boletin de la Sociedad Argentina de Botânica, vol. 10, no. 4, p. 323-327. 